\title{
Scar endometriosis: the menace of surgery
}

\author{
Aruna Nigam, ${ }^{1}$ Pikee Saxena, ${ }^{2}$ Jaya Barla, ${ }^{2}$ Puja Pathak ${ }^{2}$
}

${ }^{1}$ Department of Obstetrics and Gynaecology, Hamdard Institute of Medical Sciences and Research, New Delhi, India ${ }^{2}$ Department of Obstetrics and Gynaecology, Lady Hardinge Medical College, New Delhi, India

\section{Correspondence to} Dr Aruna Nigam, prakasharuna@hotmail.com

Accepted 29 September 2014

\section{DESCRIPTION}

A 28-year-old woman, para 2, with two previous caesarean sections, presented with pain and swelling in lower abdomen at the caesarean scar site for 6 months. The last caesarean section was performed 2 years earlier. There was no history of cyclical pain. On examination, a $3 \times 2 \mathrm{~cm}$ irregular, nodular, dark coloured, firm, immobile swelling was present on the lateral end of the caesarean scar (figure 1). The patient's general, systemic and gynaecological examination revealed no abnormality. Pelvic ultrasound detected no abnormality but in the region of the lesion it showed presence of discrete solid nodules with irregular borders surrounded by a hyperechoic rim. Differential diagnoses of scar endometriosis and stitch granuloma were made. Excision of the mass was planned. Perioperatively the lesion extended to the rectus sheath. The whole mass was excised with wide margins including the part of the rectus sheath that was involved (figure 2). Histopathological examination showed the endometrial glands mixed with stroma in fibroadipose tissue confirming the diagnosis of scar endometriosis.

Scar endometriosis is an extremely rare condition with an incidence of $0.03-0.4 \%$ and usually occurs after caesarean section. ${ }^{1}$ The interval between the surgery and the manifestation varies from 3 months to 10 years postoperatively. Swelling and pain are the most common symptoms. History of cyclical pain may be present. The differential diagnoses of such swelling include haematomas, stitch granulomas, neuromas, abscess and malignancy. Different diagnostic modalities available are ultrasonography, CT and MRI; these modalities generally guide as to depth and extent of lesion and help in planning excision. Needle aspiration cytology can also be performed before surgery if there is a suspicion of malignancy although patient history and the appearance of swelling are very much indicative of

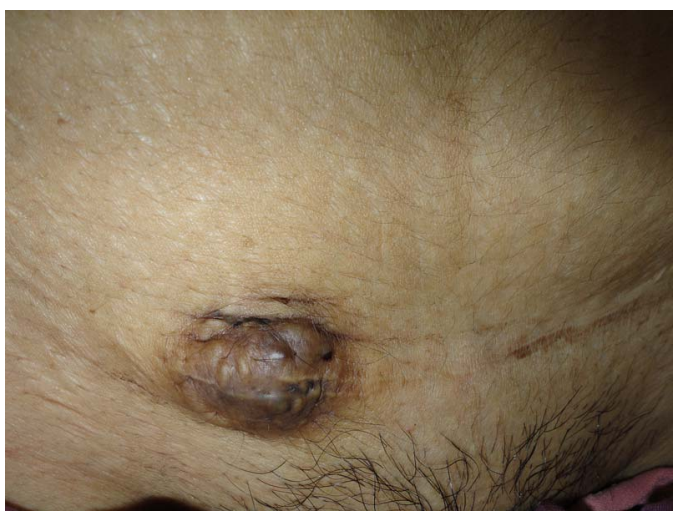

Figure 1 Lower abdominal wall showing scar endometriosis in the region of caesarean section scar.

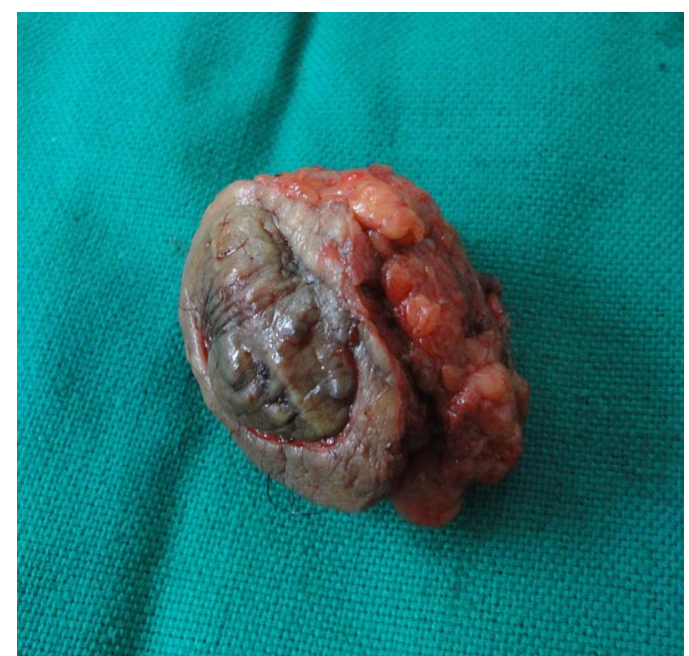

Figure 2 Tissue removed after excision.

the diagnosis. Wide excision with removal of all the endometrial tissue is the treatment of choice.

As the pathogenesis of scar endometriosis is direct inoculation during surgery, ${ }^{2}$ it is recommended to follow good surgical technique during caesarean section and irrigation of the incision site before abdominal wall closure and to use separate sponges for cleaning the uterine cavity and skin wound.

\section{Learning points}

- A patient presenting with pain and swelling in the caesarean scar region is indicative of scar endometriosis.

- Good surgical technique during caesarean section is recommended.

- Wide excision of the lesion is a rule to prevent recurrence.

\section{Competing interests None.}

Patient consent Obtained.

Provenance and peer review Not commissioned; externally peer reviewed.

\section{REFERENCES}

1 Danielpour PJ, Layke JC, Durie N, et al. Scar endometriosis-a rare cause for a painful scar: a case report and review of literature. Can J Plast Surg 2010;18:19-20.

2 Nigam A. Subcutaneous endometriosis: a rare cause of deep dyspareunia. BMJ Case Rep 2014;2014:pii: bcr2013202230 
Copyright 2014 BMJ Publishing Group. All rights reserved. For permission to reuse any of this content visit http://group.bmj.com/group/rights-licensing/permissions.

BMJ Case Report Fellows may re-use this article for personal use and teaching without any further permission.

Become a Fellow of BMJ Case Reports today and you can:

- Submit as many cases as you like

- Enjoy fast sympathetic peer review and rapid publication of accepted articles

- Access all the published articles

- Re-use any of the published material for personal use and teaching without further permission

For information on Institutional Fellowships contact consortiasales@bmjgroup.com

Visit casereports.bmj.com for more articles like this and to become a Fellow 